GRASAS Y ACEITES 69 (2)

April-June 2018, e247

ISSN-L: 0017-3495

https://doi.org/10.3989/gya.1103172

\title{
Lipase-catalyzed transesterification of epoxidized soybean oil to prepare epoxy methyl esters
}

\author{
W. Liu ${ }^{\mathrm{a}, \bowtie}$ and F. Duan ${ }^{\mathrm{a}}$ \\ ${ }^{a}$ Lipid Chemistry, College of Food Science and Technology, Henan University of Technology, Lianhua Street 100, Zhengzhou \\ 450001 , P. R. China \\ ${ }^{\otimes}$ Corresponding author: liuwei307@hotmail.com; liuwei820307@126.com
}

Submitted: 18 October 2017; Accepted: 23 January 2018

SUMMARY: Epoxidized soybean oil methyl esters could be efficiently prepared with the transesterification of epoxidized soybean oil (ESBO) with a lower dosage of methanol using lipase Novozym 435 as catalyst. The optimum parameters were as follows: the molar ratio of 5:1 (methanol to ESBO), 5\% Novozym 435 as catalyst, at $45^{\circ} \mathrm{C}$ for $14 \mathrm{~h}$, with a stirring speed of 600rpm, under which the epoxidized soybean oil methyl esters (ESBOME) could be obtained at a $95.7 \%$ yield. During the enzymatic transesterification process, the oxirane oxygen values were kept unchangeable, which indicated that excellent functional group tolerance could be achieved under such mild reaction conditions. In addition, the recyclability of the immobilized enzyme Novozym 435 in this transesterification process was examined and the results showed that the biocatalyst could be reused ten times without losing any reaction activity or selectivity. And the final products of ESBOME were also identified by IR and NMR analysis. The kinetic data obtained followed the Ping-Pong Bi mechanism model $\left(\mathrm{V}_{\max }=6.132 \mathrm{~mol} \cdot \mathrm{L}^{-1} \min ^{-1}, \mathrm{~K}_{m, S}=0.0001 \mathrm{~mol} \cdot \mathrm{L}^{-1}, \mathrm{~K}_{m, A}=796.148 \mathrm{~mol} \cdot \mathrm{L}^{-1}, \mathrm{~K}_{i, A}=0.0004 \mathrm{~mol} \cdot \mathrm{L}^{-1}\right)$ with competitive inhibition by methanol.

KEYWORDS: Bio-based products; Epoxidized soybean oil; Epoxy methyl esters; Lipase; Transesterification

RESUMEN: Transesterificación catalizada por lipasa en aceite de soja epoxidado para preparar epoxi metil ésteres. Los ésteres metílicos de aceites de soja epoxidados pueden prepararse eficientemente mediante la transesterificación del aceite de soja epoxidado (ESBO) con una menor dosificación de metanol utilizando la lipasa Novozym 435 como catalizador. Los parámetros óptimos fueron los siguientes: relación molar 5:1 de metanol:ESBO, $5 \%$ de Novozym 435 como catalizador, $45^{\circ} \mathrm{C}$ durante $14 \mathrm{~h}$, velocidad de agitación de $600 \mathrm{rpm}$, bajo la cual los ésteres metílicos de aceites de soja epoxidados (ESBOME) pueden obtenerse con un rendimiento del 95,7\%. Durante el proceso de transesterificación enzimática, los valores de oxígeno de oxirano se mantuvieron inalterables, lo que indicó que se logra una excelente estabilidad del grupo funcional en tales condiciones de reacción suaves. Además, se examinó la reciclabilidad de la enzima inmovilizada Novozym 435 en este proceso de transesterificación y los resultados mostraron que el biocatalizador podría reutilizarse durante diez veces sin perder ninguna actividad de reacción o selectividad. Los productos finales de ESBOME se identificaron por IR y análisis de RMN. Los datos cinéticos obtenidos siguieron el modelo de mecanismo Ping-Pong Bi $\left(\mathrm{V}_{\max }=6,132 \mathrm{~mol} \cdot \mathrm{L}^{-1} \min ^{-1}, \mathrm{~K}_{m, S}=0,0001 \mathrm{~mol} \cdot \mathrm{L}^{-1}, \mathrm{~K}_{m, A}=796,148 \mathrm{~mol} \cdot \mathrm{L}^{-1}, \mathrm{~K}_{i, A}=0,0004 \mathrm{~mol} \cdot \mathrm{L}^{-1}\right)$ con inhibición competitiva por metanol.

PALABRAS CLAVE: Aceite de soja epoxidado; Epoxi metil ésteres; Lipasa; Productos de base biológica; Transesterificación

ORCID ID: Liu W https://orcid.org/0000-0003-1706-1208, Duan F https://orcid.org/0000-0003-2772-9435

Citation/Cómo citar este artículo: Liu W, Duan F. 2018. Lipase-catalyzed transesterification of epoxidized soybean oil to prepare epoxy methyl esters. Grasas Aceites 69 (2), e247. https://doi.org/10.3989/gya.1103172

Copyright: (C2018 CSIC. This is an open-access article distributed under the terms of the Creative Commons Attribution 4.0 International (CC BY 4.0) License. 


\section{INTRODUCTION}

With the increasing for green processes from the modern chemical industry, bio-based products have become more and more attractive as biodegradable, nontoxic, and renewable chemical sources (Zhang et al., 2011) which can be widely used in fuels, polymers, coatings, and other specialty products. Soybean oil (SBO) is one of the most common vegetable oils used as substrates in the oleo-chemical industry, due to its cheaper price and higher output in the world's oil market.

Epoxidized soybean oils can be synthesized on a large scale with the epoxidation of soybean oil in the presence of hydrogen peroxide $\left(\mathrm{H}_{2} \mathrm{O}_{2}\right)$ and an acid catalyst (Liu et al., 2016). Epoxidized soybean oil is usually used as lubricants, plasticizers, rubber-like materials and polymer stabilizers in industry (Biermann et al., 2008; Wu et al., 2000; Hwang and Erhan, 2001; Sharma et al., 2006; Campanella et al., 2010; Noor Armylisas et al., 2017). With the rapid development of the oleochemical industry and increasing demand for renewable materials, the interest in using the epoxidized vegetable oil methyl esters as the chemical intermediate is increasing continually, such as carbonate esters and polymers (Mazo and Rios, 2013; Martini et al., 2009; Ahn et al., 2011; Mustata et al., 2014).

Recently, the transesterification of vegetable oil or animal fat with short chain alcohols (eg. methanol, ethanol) has been extensively studied. The transesterification process can usually be catalyzed by a chemical method or an enzymatic method; while the chemical method can be divided into acid or base catalysts, such as sulfuric acid (Souza et al., 2016), chlorhydric acid (Pastore et al., 2015) and sulfonic acid (Alhassan et al., 2015) as acid catalyst, or $\mathrm{NaOH}$ (Almeida et al., 2015), $\mathrm{KOH}$ (Ullah et al., 2015) and $\mathrm{NaOCH}_{3}$ (Holser, 2008) as base catalyst. With the aim of green processing in the oleo-industry, the disadvantages of these chemical methods, such as harsh reaction conditions and corrosive catalysts, retarded the development of the oleo industry. As an efficient bio-catalyst, the lipase-catalyzed transesterification of oil to prepare biodiesel (fatty acid methyl esters) has been generally accepted as a green manner by the academic and industrial world. (Bajaj et al., 2010; Guldhe et al., 2015; GutiérrezArnillas et al., 2016) For example, Zheng et al. (Zheng et al., 2009) reported that the lipase catalyzed transesterification of soybean oil with methanol to prepare biodiesel production in an organic solvent (eg. tert-amyl alcohol), showed the highest biodiesel conversion of $97 \%$ and was obtained at $40{ }^{\circ} \mathrm{C}$ for $15 \mathrm{~h}$.

Epoxidized soybean oil methyl esters can be prepared through the transesterification of epoxidized soybean oil (ESBO) with methanol in the presence of sodium methoxide as a strong base catalyst (Holser, 2008). Considering the moisture sensitivity of $\mathrm{NaOCH}_{3}$ and the possible dangers in large scale processes (Kwok et al., 2013; Kai et al., 2014; Lin et al., 2014), sustainable and green methods (eg. enzymatic method) are highly desirable for the transesterification of epoxidized vegetable oils to prepare epoxy methyl ester products under mild conditions (Scheme 1).

In this work, we chose one of the most commonly used commercial immobilized lipases for biodiesel production, Novozym 435, as a biocatalyst to prepare epoxidized soybean oil methyl ester (ESBOME) with epoxidized soybean oil and methanol in a solvent-free system. The effects of catalyst loading, reaction time, methanol to oil molar ratio, reaction temperature and stirring speed on the transesterification yield were investigated. The recyclability of the biocatalyst Novozym 435 in this transesterification process was also evaluated.

\section{MATERIALS AND METHODS}

\subsection{Materials}

Epoxidized soybean oil was purchased from Aladdin Chemical Reagent (Shanghai, China). Novozym 435 (Candida antarctica lipase immobilized on polyacrylic resin, 10,000 PLU/g) was purchased from Novozymes A/S (Bagsvaerd,
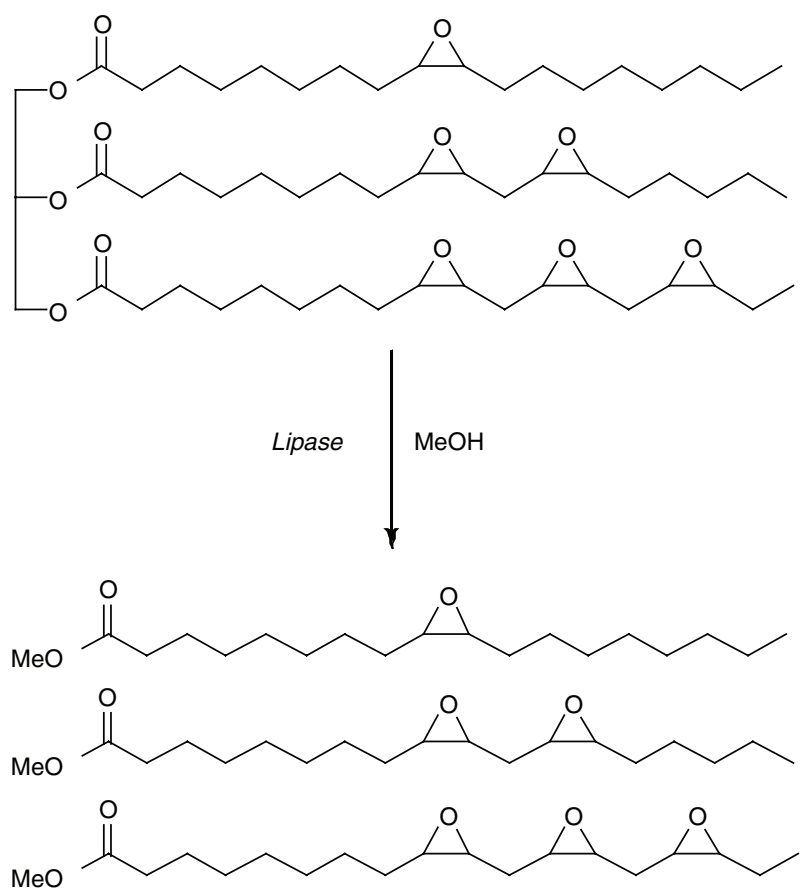

SCHEME 1. Enzymatic transesterification of ESBO with methanol. 
Denmark). Methanol and n-hexane were analytical reagent grade and purchased from Kermel Chemical Reagent (Tianjin, China). Monoglyceride (analytical standard), diglyceride (95\%) standards were purchased from Sigma-Aldrich Co. (St. Louis, MO). Triglyceride (>99\%, soybean oil) was purchased from a local supermarket (Zhengzhou, China).

\subsection{Transesterification}

Transesterification reactions were performed in $50 \mathrm{~mL}$ round-bottom flasks. Epoxidized soybean oil $(10.0 \mathrm{~g})$ was introduced to the flask and a certain amount of Novozym 435 catalyst and methanol were added. Then the mixture was magnetically stirred at a controlled temperature for $6-18 \mathrm{~h}$. To note, the sample was a mixture in stirring. After stopping stirring for 3-5 minutes, a phase separation between the formed glycerol and the FAME was observed. After completion of the reaction, the Novozym 435 was removed by filtration, then the product was washed with saturated brines to remove the remaining methanol and glycerol. The remaining water was dried by anhydrous sodium sulfate $\left(\mathrm{Na}_{2} \mathrm{SO}_{4}\right)$. Finally, the product was dried under reduced pressure for $1 \mathrm{~h}$ at room temperature.

\subsection{Oxirane oxygen titrations}

Epoxy oxygen group content (EOC) was determined by the titration method with a hydrobromic acid solution in acetic acid following AOCS standard test method Cd 9-57 (AOCS, 1998).

\subsection{Gas chromatography analysis}

Samples were analyzed with an Agilent 7890 gas chromatograph (GC) using a DB-1HT column $(30 \mathrm{~m} \times 0.25 \mathrm{~mm} \times 0.1 \mu \mathrm{m}, \mathrm{J} \& \mathrm{~W}$ Scientific, Folsom, CA). The carrier gas was Nitrogen flowing at $5 \mathrm{~mL} \cdot \mathrm{min}^{-1}$. The oven was programmed from an initial temperature of $50-180{ }^{\circ} \mathrm{C}$ at $15{ }^{\circ} \mathrm{C} \cdot \mathrm{min}^{-1}$, increased to $230{ }^{\circ} \mathrm{C}$ at $7{ }^{\circ} \mathrm{C} \cdot \mathrm{min}^{-1}$, and then to $380{ }^{\circ} \mathrm{C}$ at $30{ }^{\circ} \mathrm{C} \cdot \mathrm{min}^{-1}$ with a $15 \mathrm{~min}$ hold for a total run time of $35 \mathrm{~min}$. The injection volume was $1 \mu \mathrm{L}$ with the inlet set to splitless mode. The detection of eluents was made by the flame ionization detector (FID) and identified by comparing the retention times to known standards. Fatty acid esters, monoglyceride, diglyceride, and triglyceride standards were used. The ESBOME yield was calculated based on the following equation (Silitonga et al., 2016):

$$
\text { ESBOME Yield }(\mathrm{wt} \%)=\frac{\begin{array}{c}
\text { Weight of ESBOME } \\
\text { produced }(\mathrm{g})
\end{array}}{\begin{array}{c}
\text { Weight of ESBO } \\
\text { used }(\mathrm{g})
\end{array}} \times 100 \%
$$

\subsection{Kinetic experiment}

Six experiments were performed at different molar ratios of oil to methanol from 1:1 to 1:7.5 in $50 \mathrm{~mL}$ round-bottom flasks. At pre-determined times, $0.3 \mathrm{~mL}$ samples were taken, dissolved in $5 \mathrm{~mL}$ n-hexane, and centrifuged to obtain the upper layer for gas chromatography analysis, 17:0 methyl ester as internal standard.

\section{6. ${ }^{1}$ HNMR analysis}

Samples were analyzed with a Bruker AVANCE III NMR. 1HNMR spectra were obtained at 500 $\mathrm{MHz}$. And $\mathrm{CDCl}_{3}$ was used as solvent for the sample. The chemical shifts were quoted in parts per million (ppm) and referenced to as $0 \mathrm{ppm}$ for internal tetramethylsilane (TMS).

\section{RESULTS AND DISCUSSION}

\subsection{Effect of reaction time}

Reaction time is one of the most important factors affecting enzymatic transesterification reactions. According to previous work on enzymatic transesterification (Kwok et al., 2013), the optimum reaction time was determined to be $24 \mathrm{~h}$. Therefore, $6 \mathrm{~h}$ to $18 \mathrm{~h}$ were selected as the reaction times in this experiment. As shown in Figure 1, when the enzymatic transesterification reaction time was increased from 6 to $16 \mathrm{~h}$, the yield of ESBOME was increased from $75.4 \%$ to $90.1 \%$. When the reaction time was increased to $18 \mathrm{~h}$, the yield of ESBOME exhibited a slight decrease $(85.2 \%)$. The oxirane oxygen value was reduced from $6.1 \mathrm{wt} \%$ to $5.8 \mathrm{wt} \%$ when the reaction time changed from $6 \mathrm{~h}$ to $16 \mathrm{~h}$. The oxirane oxygen value of ESBO

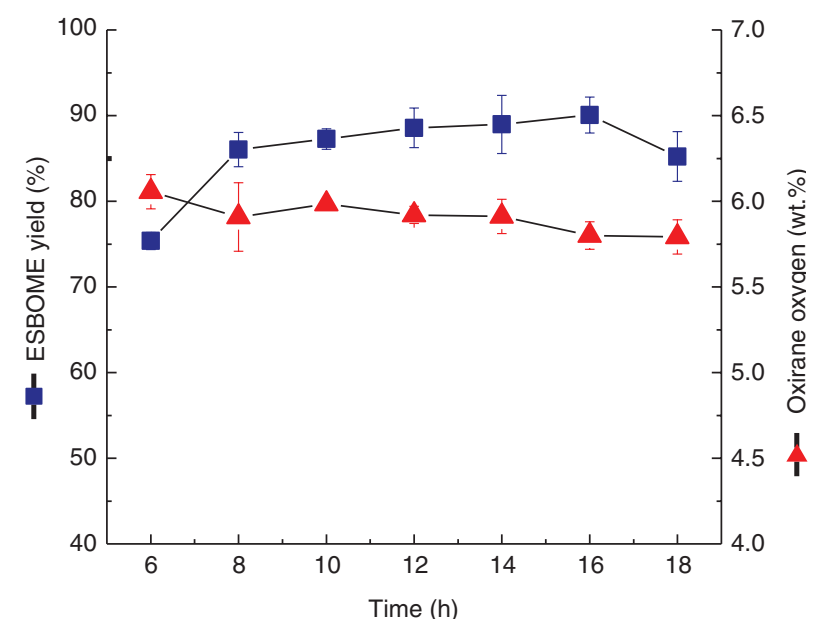

FIGURE 1. Effect of reaction time on transesterification reactions and oxirane oxygen values (Reaction conditions: 55 ${ }^{\circ} \mathrm{C}, 6: 1$ of methanol to oil molar ratio, $10 \%$ (wt $\%$ of oil) of Novozym 435, stirring speed 600rpm). Error bars indicate the $\mathrm{SD}$ of the mean of three replicates $(n=3)$. 
was lower than $5.8 \mathrm{wt} \%$ after reaction for $16 \mathrm{~h}$. Considering a longer reaction time would lead to the hydrolysis of the epoxide group. The optimal transesterification reaction time was $14 \mathrm{~h}$ and the yield of ESBOME could reach to $89.0 \%$ under such reaction conditions. In addition, the contents of monoglycerides and diglycerides in the final products were analyzed by GC after $14 \mathrm{~h}$ (Figure 2), and the results showed that the methyl ester content of ESBOME could reach $98.6 \%$. Though trace amounts of $\mathrm{MG}$ may be present, the purity of the methyl ester product after the simple purification was relatively higher.

\subsection{Effect of catalyst loading}

Novozym 435 is one of the most effective and widely used bio-catalysts in many organic transformations (Zheng et al., 2009; Gutiérrez-Arnillas et al., 2016; Rosa et al., 2009), which could lower the activation energy for the reactant and increase activated molecules in the reaction system. In this experiment, ESBOME was prepared through the transesterification of ESBO at $55^{\circ} \mathrm{C}$ for $14 \mathrm{~h}$ with Novozym 435 as bio-catalyst and different catalyst loading (1\%-15\%) was investigated. As shown in Figure 3, when the amount of Novozym 435 was increased from $1 \%$ to $10 \%$, the ESOME yield was gradually improved. However, when the amount reached $15 \%$, the ESOME yield was slightly lower, because the excess amount of Novozym 435 could also accelerate the side reactions at the same time. When the amount of Novozym 435 was increased from $5 \%$ to $10 \%$, the ESOME yield was slightly enhanced from $93.2 \%$ to $93.9 \%$. With the increase in the amount of Novozym 435, oxirane oxygen values were maintained at around $6.0 \mathrm{wt} \%$. Considering the reaction activity and the cost of scalable production for bio-based products, a $5 \%$ amount of Novozym 435 was chosen as the optimal amount of bio-catalyst used in the following experiments.



FIGURE 2. Gas Chromatograms of: (A) monoglyceride (MG), diglyceride (DG), and triglyceride (TG) standard compounds; (B) transesterification of epoxidized soybean oil after $14 \mathrm{~h}$

\subsection{Effect of methanol/oil molar ratio}

The molar ratio of methanol/ESBO strongly affects the transesterification reaction rate and conversion. Because the stoichiometric molar ratio of methanol to epoxidized soybean oil (ESBO) was $3: 1$ according to the transesterification reaction, an excess of methanol was used to ensure the complete conversion of epoxidized soybean oil. However, a higher methanol ratio would lead to the denaturation and inactivation of the lipase. In this experiment, the different molar ratios of methanol/ ESBO ranged from 3:1 to 7:1 and were evaluated in Figure 4. In general, a greater amount of methanol (5:1 molar ratio of methanol to ESBO) used in the

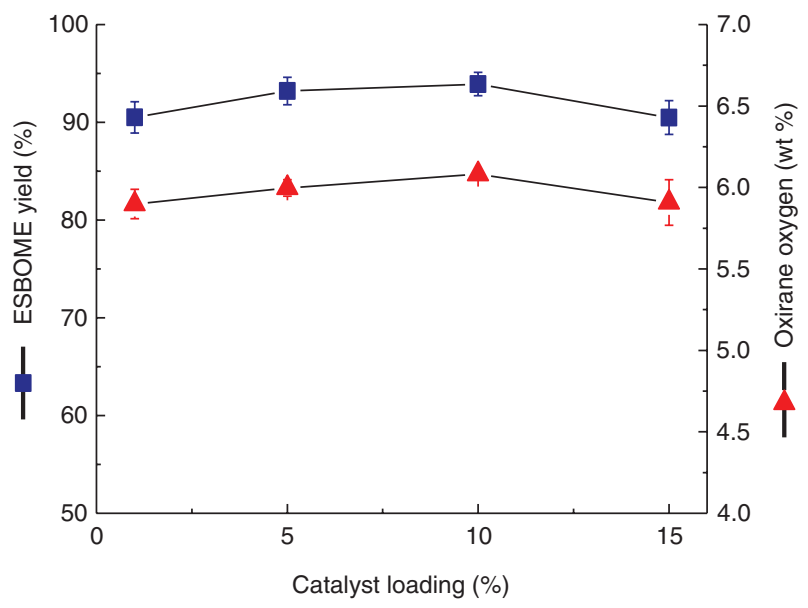

FIGURE 3. Effect of catalyst loading on transesterification reactions and oxirane oxygen values (Reaction conditions: $55^{\circ} \mathrm{C}, 14 \mathrm{~h}, 6: 1$ of methanol to oil molar ratio, stirring speed $600 \mathrm{rpm})$. Error bars indicate the SD of the mean of three replicates $(n=3)$

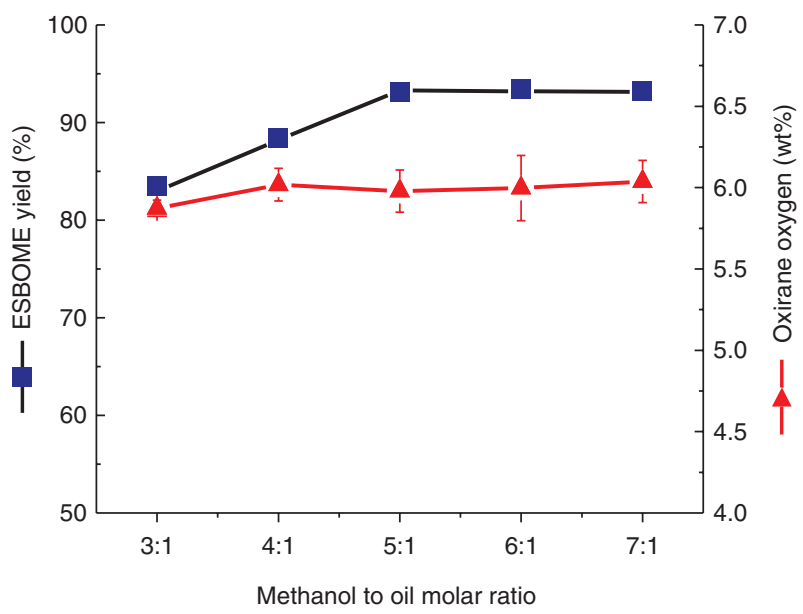

FIGURE 4. Effect of methanol/oil molar ratio on transesterification reactions and oxirane oxygen values (Reaction conditions: $55^{\circ} \mathrm{C}, 14 \mathrm{~h}, 5 \%$ of Novozym 435 , stirring speed $600 \mathrm{rpm})$. Error bars indicate the SD of the mean of three replicates $(n=3)$ 
transesterification reaction led to a higher yield of ESBOME $(93.3 \%)$. With a continuing increase in the molar ratio of methanol to ESBO from 5:1 to $7: 1$, the methyl ester yield had practically no change. It is important to note that the change in molar ratio of methanol to EBSO could not affect the epoxide group, which indicated that this established enzymatic transesterification method was mild enough for such unstable epoxide groups. Therefore, the optimal molar ratio of methanol to ESBO was 5:1 and the yield of ESBOME was able to reach $93.3 \%$.

\subsection{Effect of reaction temperature}

The reaction temperature not only affects the activity of Lipase Novozym 435, but also the percent of activated molecules in the reactants such as methanol and triglycerides. Moreover, the increase in reaction temperature can decrease the viscosity of ESBO and affect the thermodynamic equilibrium of enzymecatalyzed reactions (Rosa et al., 2009). Based on the studies involving Novozym 435 as catalyst (Zhang et al., 2011), a range of reaction temperature $\left(25^{\circ} \mathrm{C}-55\right.$ C) was investigated in this work (Figure 5). When the reaction temperature was increased from $25^{\circ} \mathrm{C}$ to $45^{\circ} \mathrm{C}$, the ESBOME yield was improved from $90.7 \%$ to $95.7 \%$. The ESBOME yield was similar at $55^{\circ} \mathrm{C}$. Meanwhile, the oxirane oxygen values did not change when the reaction temperature changed from $35^{\circ} \mathrm{C}$ to $55^{\circ} \mathrm{C}$. Therefore, $45^{\circ} \mathrm{C}$ was selected as the optimal reaction temperature and the yield of ESBOME reached $95.7 \%$ under such reaction conditions.

\subsection{Effect of stirring speed}

The stirring speed can make contact in the substrates more efficient, so that stirring can improve the reaction rate in most cases (Gharat et al., 2013).

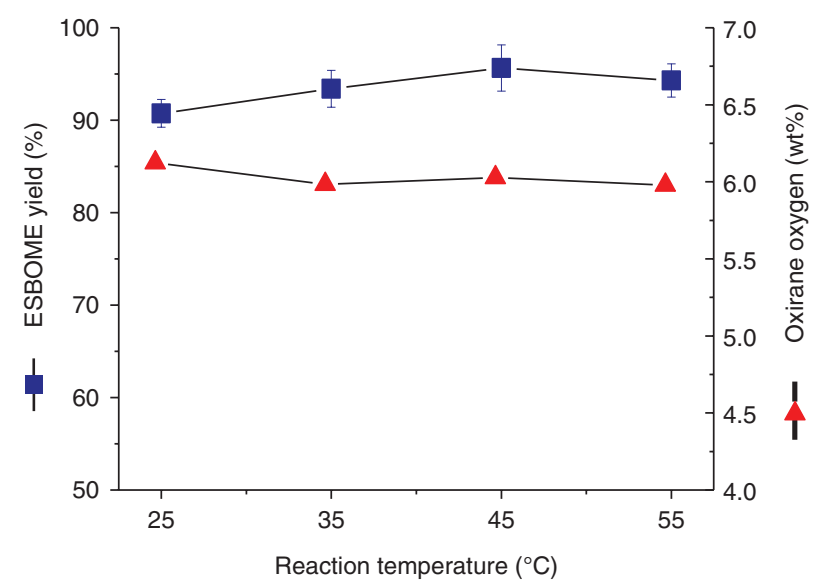

FIGURE 5. Effect of reaction temperature on transesterification reactions and oxirane oxygen values (Reaction conditions: $5: 1$ of methanol to oil molar ratio, $5 \%$ of Novozym $435,14 \mathrm{~h}$, stirring speed 600rpm). Error bars indicate the SD of the mean of three replicates $(n=3)$
It could be seen from Fig. 6 that with an increase in stirring speed from $200 \mathrm{rpm}$ to $600 \mathrm{rpm}$, the yield of ESBOME increased from $69.9 \%$ to $95.7 \%$. With the increase in stirring speed, the oxirane oxygen values were changed from $6.3 \mathrm{wt} \%$ to $6.0 \mathrm{wt} \%$. Considering $600 \mathrm{rpm}$ as the maximum stirring speed in this experiment, $600 \mathrm{rpm}$ was selected as the optimal stirring speed and the highest yield of methyl esters was $95.7 \%$ under such reaction conditions.

\subsection{Recycling of Novozym 435}

The reusability of Novozym 435 in the transesterification reactions was also investigated based on the selected conditions obtained above. The changing trend of the ESBOME yield, the methyl ester content and the oxirane oxygen values are shown in Figure 7 when the Novozym 435 was reused. From Figure 7, it can be determined that the lipase could be used at least 10 times without losing any activity, as the ESBOME yield, the methyl ester content and the oxirane oxygen values were changed within very small ranges, from $95.7 \%$ to $96.7 \%$, from $98.7 \%$ to $100.0 \%$, from $5.7 \mathrm{wt} \%$ to $6.3 \mathrm{wt} \%$, respectively. The above results suggested that the activity of Novozym 435 could be well kept due to the mild reaction temperature $\left(45^{\circ} \mathrm{C}\right)$ and lower dosage of methanol solvent (5:1 of methanol/oil molar ratio) in the reaction system.

\subsection{Determination of molecule structure of methyl esters by IR and NMR}

The final product of the transesterification of epoxidized soybean oil (ESBO) with methanol was identified by IR and ${ }^{1} \mathrm{H}$ NMR (Figures 8 and 9). The characteristic absorption peaks of ESBOME (carbonyl group, ester group and epoxy group)

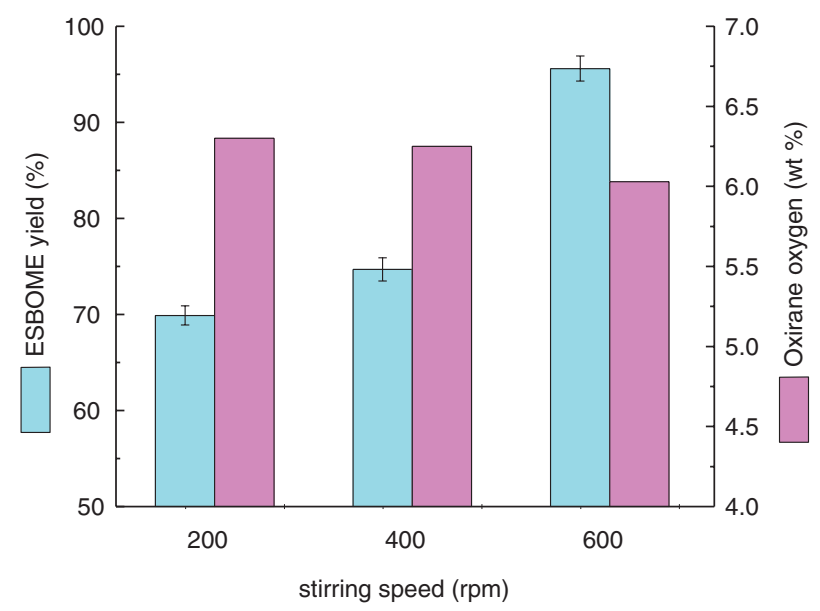

FIGURE 6. Effect of speed agitation on transesterification reactions and oxirane oxygen values (Reaction conditions: $45^{\circ} \mathrm{C}$, $5: 1$ of methanol/oil molar ratio, $5 \%$ of Novozym $435,14 \mathrm{~h}$ ). Error bars indicate the SD of the mean of three replicates $(n=3)$. 
(A)



(B)

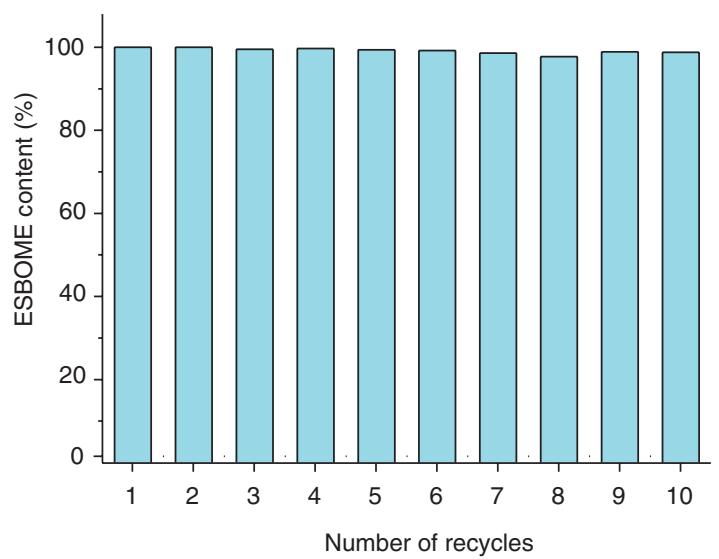

(C)

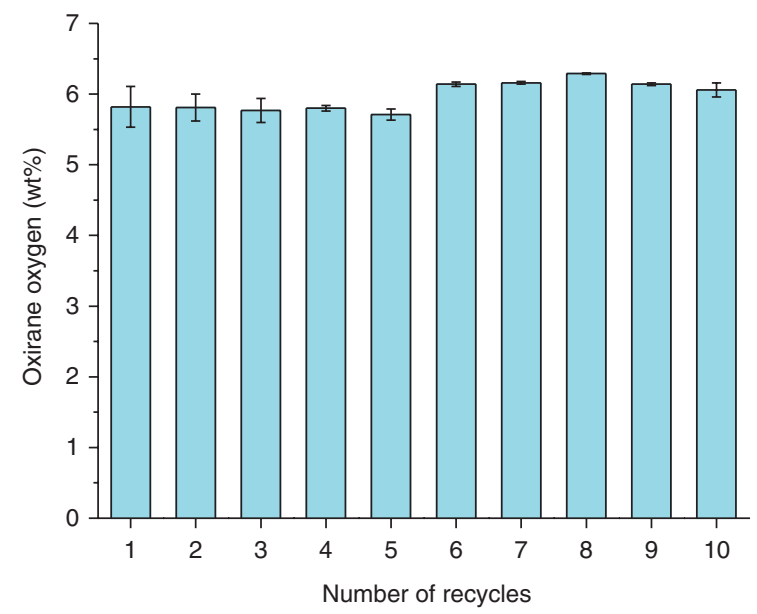

FIGURE 7. Effect of Novozym 435 recycling on transesterification reactions: ESBOME yield (A); ESBOME content (B) and oxirane oxygen values (C). (Reaction conditions: $45^{\circ} \mathrm{C}, 5: 1$ of methanol/oil molar ratio, 5\% of Novozym 435 , $14 \mathrm{~h}$, stirring speed $600 \mathrm{rpm}$ ). Error bars indicate the $\mathrm{SD}$ of the mean of three replicates $(\mathrm{n}=3)$

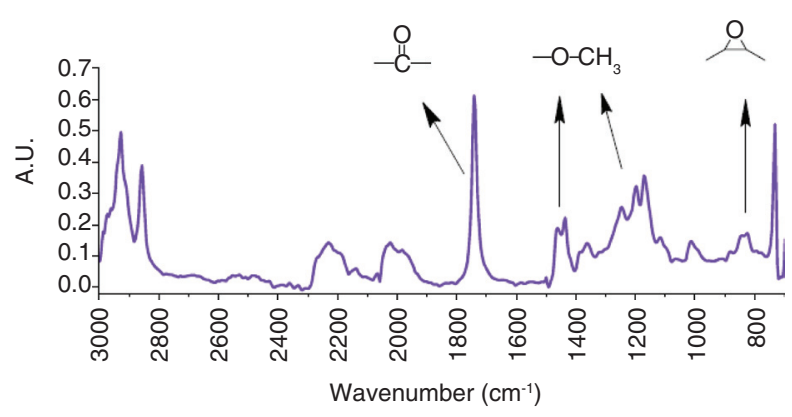

FIGURE 8. IR spectrum of epoxy oil methyl esters

appeared on its FT-IR spectrum. As shown in Figure 9, the protons of the epoxy groups (a) were at $3.0 \mathrm{ppm}$ and methyl ester protons (ME) (b) were at $3.6 \mathrm{ppm}$, which undoubtedly suggested that epoxidized soybean oil methyl esters (ESBOME) could be obtained without a loss in epoxide function. The above results obtained by NMR were similar to those reported by Knothe (Knothe et al., 2001) and Y. C. Sharma. (Sharma et al., 2010).

\subsection{Kinetic analysis of transesterification}

A kinetic model was established for the transesterification of ESBO with methanol catalyzed by Novezym-435 lipase. The process for ESBOME concentration-time profiles for different methanol concentrations is shown in Figure 10. In this system, methanol concentrations gradually increased, and the amount of ESBO should be fixed. When the ratio of oil to methanol was below 1:5, the reaction rate obviously increased. When the ratio of oil to methanol was higher than $1: 5$, the reaction rate decreased, due to the inhibition of methanol (Trinh et al., 2018). The optimal ratio of oil to methanol as 


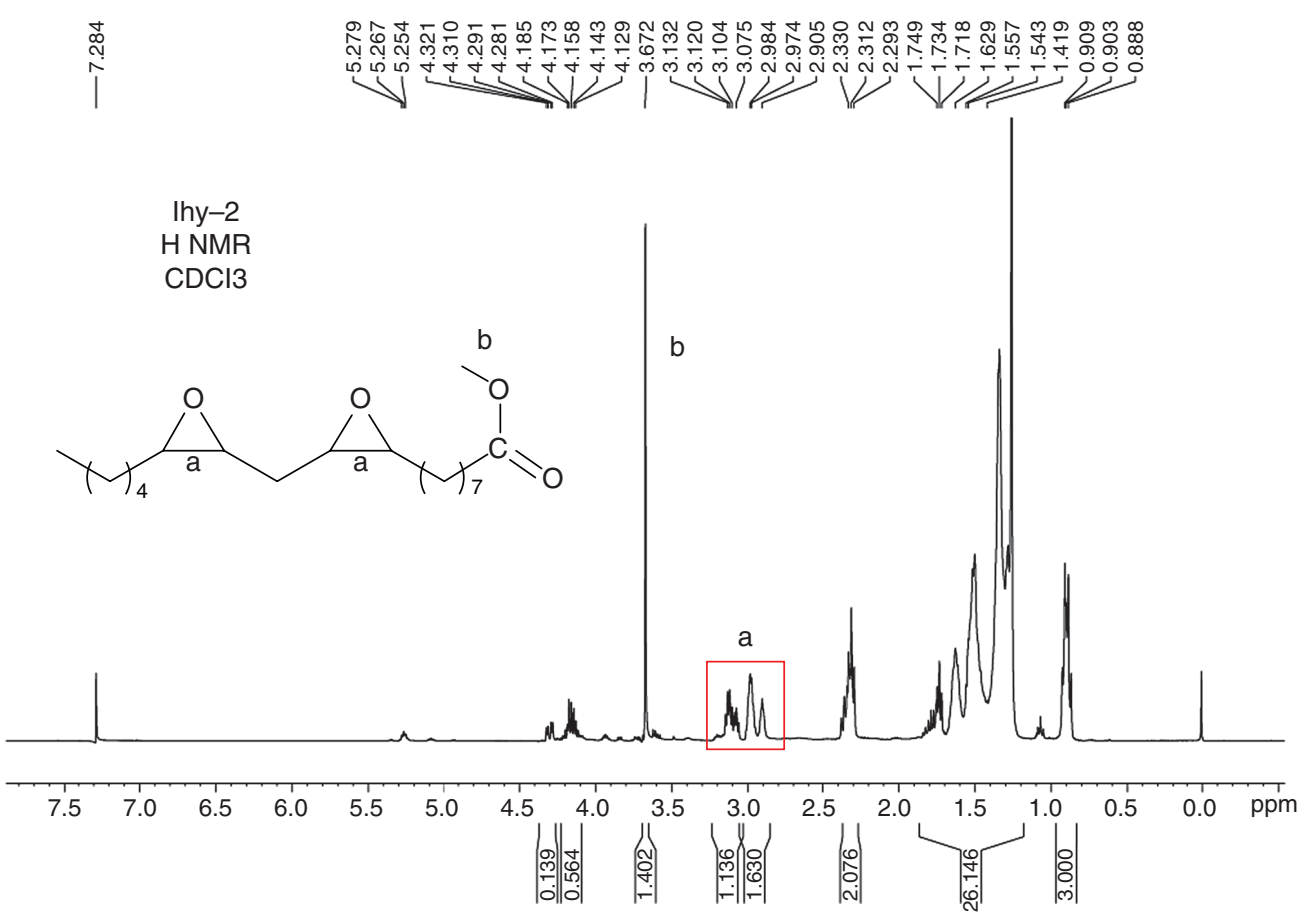

Figure 9. ${ }^{1} \mathrm{H}$ NMR of epoxy oil methyl esters

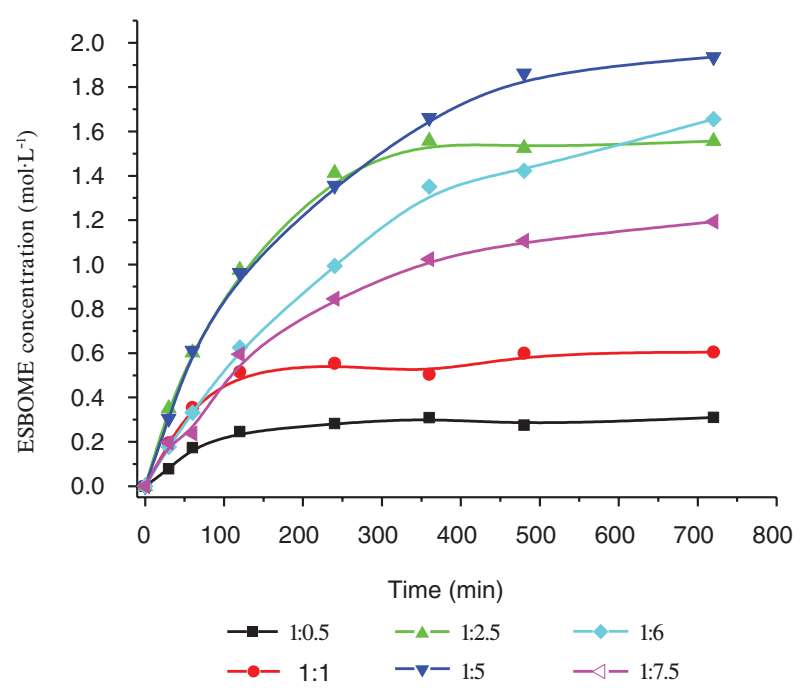

FigURE 10. ESBOME concentration-time profiles for different methanol concentrations. (Reaction conditions: $45^{\circ} \mathrm{C}, 5 \%$ of Novozym 435, 14h, stirring speed $600 \mathrm{rpm}$ )

seen in Figure 10 was same as the result of the single factor optimal reaction. Previously it was suggested that the enzymatic transesterification of triglycerides could be described by a Ping-Pong Bi mechanism with methanol inhibition (Ilmi et al., 2016).

The kinetic model was set-up on the basis of the following assumptions: (1) The polarity of epoxidized soybean oil was better than soybean oil for mutual solubility with methanol. Under stirring, the mix was a homogeneous mixture. (2) In the
TABLE. 1. Comparison of kinetic parameters with related transesterification reactions.

\begin{tabular}{lc}
\hline Parameters & value \\
\hline $\mathrm{V}_{\max }\left(\mathrm{mol} \cdot \mathrm{L}^{-1} \mathrm{~min}^{-1}\right)$ & 6.132 \\
$\mathrm{~K}_{\mathrm{m}, \mathrm{S}}\left(\mathrm{mol} \cdot \mathrm{L}^{-1}\right)$ & 0.0001 \\
$\mathrm{~K}_{\mathrm{m}, \mathrm{A}}\left(\mathrm{mol} \cdot \mathrm{L}^{-1}\right)$ & 796.148 \\
$\mathrm{~K}_{\mathrm{i}, \mathrm{A}}\left(\mathrm{mol} \cdot \mathrm{L}^{-1}\right)$ & 0.0004 \\
\hline
\end{tabular}

initial stage of the reaction, the production was low and the inhibition of ESBOME and glycerin was ignored. (3) One of the substrates was oil without inhibition to Novezym-435, but another substrate was methanol with obvious inhibition.

The Ping Pong mechanism inhibition of methanol can be expressed as follows:

$$
v=\frac{v_{\max }}{1+\frac{K_{m, A}}{[A]}+\frac{K_{m, s}}{[S]}\left[1+\frac{[A]}{K_{i, A}}\right]}
$$

Here $[\mathrm{S}]$ denotes the oil concentration, $[\mathrm{A}]$ the methanol concentration, $\mathrm{K}_{\mathrm{m}, \mathrm{S}}$ and $\mathrm{K}_{\mathrm{m}, \mathrm{A}}$ denote the dissociation constants of oil and methanol, respectively, and $\mathrm{K}_{\mathrm{i}, \mathrm{A}}$ the inhibition constants of methanol.

The data were analyzed by non-linear regression and the kinetic parameters were determined by the Origin, as shown in Table 1. The values obtained for the kinetic data were $\mathrm{Vmax}=6.132 \mathrm{~mol} \cdot \mathrm{L}^{-1} \mathrm{~min}^{-1}$, $\mathrm{K}_{\mathrm{m}, \mathrm{S}}=0.0001 \mathrm{~mol} \cdot \mathrm{L}^{-1}, \mathrm{~K}_{\mathrm{m}, \mathrm{A}}=796.148 \mathrm{~mol} \cdot \mathrm{L}^{-1}$, 
$\mathrm{K}_{\mathrm{i}, \mathrm{A}}=0.0004 \mathrm{~mol} \cdot \mathrm{L}^{-1}$. This suggests that the proposed model for the Novezym 435 catalyzed transesterification of ESBO and methanol is valid.

\section{CONCLUSIONS}

Epoxidized soybean oil methyl esters could be efficiently prepared through the transesterification of epoxidized soybean oil (ESBO) with methanol in a solvent-free system using lipase Novozym 435 as catalyst. The optimized conditions were as follows: lower dosage of methanol (the molar ratio of methanol to ESBO 5:1), 5\% Novozym 435 as catalyst, at $45{ }^{\circ} \mathrm{C}$ for $14 \mathrm{~h}$, with a stirring speed of 600 rpm, under which the epoxidized soybean oil methyl esters (ESBOME) could be obtained at a $95.7 \%$ yield. During the enzymatic transesterification process, the oxirane oxygen values were kept unchangeable, which indicated that excellent functional group tolerance could be achieved under such mild reaction conditions. In addition, the recyclability of Novozym 435 in this transesterification process was examined and the results showed that the bio-catalyst could be reused ten times without losing any reaction activity or selectivity. The final product of ESBOME was identified by IR and ${ }^{1} \mathrm{HNMR}$ analysis. This established enzymatic transesterification of epoxidized soybean oil will provide an efficient method to produce multipurpose bio-based products. And the obtained kinetic data followed the Ping-Pong $\mathrm{Bi}$ mechanism model $\left(\mathrm{Vmax}=6.132 \mathrm{~mol} \cdot \mathrm{L}^{-1} \min ^{-1}, \mathrm{~K}_{\mathrm{m}, \mathrm{S}}=0.0001 \mathrm{~mol} \cdot \mathrm{L}^{-1}\right.$, $\mathrm{K}_{\mathrm{m}, \mathrm{A}}=796.148 \mathrm{~mol} \cdot \mathrm{L}^{-1}, \mathrm{~K}_{\mathrm{i}, \mathrm{A}}=0.0004 \mathrm{~mol} \cdot \mathrm{L}^{-1}$ ) with competitive inhibition by methanol.

\section{ACKNOWLEDGMENTS}

This work was supported by the Young-aged Backbone Teacher Funds of Henan Province of China (No. 2014GGJS-058) and Basic Research Funds in the Henan University of Technology (No. 2015RCJH01).

\section{REFERENCES}

Ahn K, Kraft S, Sun S. 2011. Chemical pathways of epoxidized and hydroxylated fatty acid methyl esters and triglycerides with phosphoric acid. J. Mater. Chem. 21, 9498-9505. https://doi.org/10.1039/c1jm10921a

Alhassan Y, Kumar N, Bugaje IM. 2015. Catalytic upgrading of waste tire pyrolysis oil via supercritical esterification with deep eutectic solvents (green solvents and catalysts). J. Energy. Inst. 89, 683-693. https://doi.org/10.1016/j. joei.2015.05.003

Almeida VFD, García-Moreno PJ, Guadix A, Guadix EM. 2015. Biodiesel production from mixtures of waste fish oil, palm oil and waste frying oil: Optimization of fuel properties. Fuel Process. Technol. 133, 152-160. https://doi. org/10.1016/j.fuproc.2015.01.041

Armylisas AHN, Hazirah MFS, Yeong SK, Hazimah AH. 2017. Modification of olefinic double bonds of unsaturated fatty acids and other vegetable oil derivatives via epoxidation: A review. Grasas Aceites 68, e174. https://doi.org/10.3989/ gya.0684161
Bajaj A, Lohan P, Jha PN, Mehrotra R. 2010. Biodiesel production through lipase catalyzed transesterification: An overview. J. Mol. Catal. B-Enzym. 62, 9-14. https://doi. org/10.1016/j.molcatb.2009.09.018

Biermann U, Friedt W, Lang S, Lühs W.; Machmüller G, Metzger JO, Klaas MR, Shafer HJ, Schneider MP. 2008. Chapter 8. New Syntheses with Oils and Fats as Renewable Raw Materials for the Chemical Industry. Biorefineries-Industrial Processes and Products: Status Quo and Future Directions. 253-289. https://doi.org/10.1002/9783527619849.ch25

Campanella A, Rustoy E, Baldessari A, Baltanás MA. 2010. Lubricants from chemically modified vegetable oils. Biotechnol. Tech. 10, 1245-1254. https://doi.org/10.1016/j. biortech.2009.08.035

Gharat N, Rathod VK. 2013. Ultrasound assisted enzyme catalyzed transesterification of waste cooking oil with dimethyl carbonate. Ultrason. Sonochem. 20, 900-905. https://doi. org/10.1016/j.ultsonch.2012.10.011

Guldhe A, Singh B, Mutanda T, Permaul K, Bux F. 2015. Advances in synthesis of biodiesel via enzyme catalysis: Novel and sustainable approaches. Renew. Sustain. Energ. Rev. 41, 1447-1464. https://doi.org/10.1016/j.rser.2014.09.035

Gutiérrez-Arnillas E, Alvarez MS, Deive FJ, Rodríguez A, Sanrom MA. 2016. New horizons in the enzymatic production of biodiesel using neoteric solvents. Renew. Energ. 98, 92-100. https://doi.org/10.1016/j.renene.2016.02.058

Holser RA. 2008. Transesterification of epoxidized soybean oil to prepare epoxy methyl esters. Ind. Crop Prod. 27, 130132. https://doi.org/10.1016/j.indcrop.2007.06.001

Hwang HS, Erhan SZ. 2001. Modification of epoxidized soybean oil for lubricant formulations with improved oxidative stability and low pour point. J. Am. Oil Chem. Soc. 78, 1179-1184. https://doi.org/10.1007/s11745-001-0410-0

Ilmi M, Hommes A, Winkelman JGM, Hidayat C, Heeres HJ. 2016. Kinetic studies on the transesterification of sunflower oil with 1-butanol catalyzed by Rhizomucor miehei lipase in a biphasic aqueous-organic system. Biochem. Eng. $J .114,110-118$. https://doi.org/10.1016/j.bej.2016.06.026

Kai T, Mak GL, Wada S, Nakazato T, Takanashi H, Uemura Y. 2014. Production of biodiesel fuel from canola oil with dimethyl carbonate using an active sodium methoxide catalyst prepared by crystallization. Biotechnol. Tech. 163, 360-363. https://doi.org/10.1016/j.biortech.2014.04.030

Knothe, G. 2001. Characterization of esters of fatty acids and dicarboxylic acids with Guerbet alcohols. J. Am. Oil Chem. Soc. 78, 537-540. https://doi.org/10.1007/ s11746-001-0299-7

Kwok Q, Acheson B, Turcotte R, Janès A, Marlair G. 2013. Fire and explosion hazards related to the industrial use of potassium and sodium methoxides. J. Hazard. Mater. 250-251, 484-490. https://doi.org/10.1016/j.jhazmat.2013.01.075

Lin YC, Hsu KH, Lin JF. 2014. Rapid palm-biodiesel production assisted by a microwave system and sodium methoxide catalyst. Fuel 115, 306-311. https://doi.org/10.1016/j. fuel.2013.07.022

Liu W, Chen J, Liu RL, Bi YL. 2016. Revisiting the Enzymatic Epoxidation of Vegetable Oils by Perfatty Acid: Perbutyric Acid Effect on the Oil with Low Acid Value. J. Am. Oil Chem. Soc. 93, 1479-1486. https://doi.org/10.1007/s11746-016-2897-3

Martini DDS, Braga BA, Samios D. 2009. On the curing of linseed oil epoxidized methyl esters with different cyclic dicarboxylic anhydrides. Polym. 50, 2919-2925. https://doi. org/10.1016/j.polymer.2009.03.058

Mazo P, Rios L 2013 Carbonation of Epoxidized Soybean Oil Improved by the Addition of Water. J. Am. Oil Chem. Soc. 90, 725-730. https://doi.org/10.1007/s11746-013-2214-3

Mustata F, Nita T, Bicu I. 2014. The curing reaction of epoxidized methyl esters of corn oil with Diels-Alder adducts of resin acids. The kinetic study and thermal characterization of crosslinked products. J. Anal. Appl. Pyrolysis, 108, 254264. https://doi.org/10.1016/j.jaap.2014.04.007

Pastore C, Barca E, Moro GD, Lopez A, Mininni G, Mascolo G. 2015. Recoverable and reusable aluminium solvated species used as a homogeneous catalyst for biodiesel production from brown grease. Appl. Catal. A: General. 501, 48-55. https://doi.org/10.1016/j.apcata.2015.04.031 
Rosa CD, Morandim MB, Ninow JL, Oliveira D, Treichel H, Oliveira JV. 2009. Continuous lipase-catalyzed production of fatty acid ethyl esters from soybean oil in compressed fluids. Bioresour. Technol. 100, 5818-5826. https://doi. org/10.1016/j.biortech.2009.06.081

Sharma BK, Adhvaryu A, Liu ZS, Erhan SZ. 2006. Chemical modification of vegetable oils for lubricant applications. $J$. Am. Oil Chem. Soc. 83, 129-136. https://doi.org/10.1007/ s11746-006-1185-Z

Sharma YC, Singh B. 2010. A hybrid feedstock for a very efficient preparation of biodiesel. Fuel Process. Technol. 91, 1267-1273. https://doi.org/10.1016/j.fuproc.2010.04.008

Silitonga AS, Masjuki HH, Hwai OC, Yusaf T, Kusumo F, Mahlia TMI. 2016. Synthesis and optimization of Hevea brasiliensis and Ricinus communis as feedstock for biodiesel production: a comparative study. Ind. Crop. Prod. 85, 274286. https://doi.org/10.1016/j.indcrop.2016.03.017

Souza GK, Scheufele FB, Pasa TLB, Arroyo PA, Pereira NC. 2016. Synthesis of ethyl esters from crude macauba oil (Acrocomia aculeata) for biodiesel production. Fuel. 165, 360-366. https://doi.org/10.1016/j.fuel.2015.10.068
Trinh H, Yusup S, Uemura Y. 2018. Optimization and kinetic study of ultrasonic assisted esterification process from rubber seed oil. Bioresour. Technol. 247, 51-57. https://doi. org/10.1016/j.biortech.2017.09.075

Ullah K, Ahmad M, Sofia, Qiu FX. 2015. Assessing the experimental investigation of milk thistle oil for biodiesel production using base catalyzed transesterification. Energy 89, 887-895. https://doi.org/10.1016/j.energy.2015.06.028

Wu XD, Zhang XG, Yang SR, Chena Hg, Wang DP. 2000. The study of epoxidized rapeseed oil used as a potential biodegradable lubricant. J. Am. Oil Chem. Soc. 77, 561-563. https://doi.org/10.1007/s11746-000-0089-2

Zhang KP, Lai JQ, Huang ZL, Yang Z. 2011. Penicillium expansum lipase-catalyzed production of biodiesel in ionic liquids. Biotechnol. Tech. 102, 2767-2772. https://doi. org/10.1016/j.biortech.2010.11.057

Zheng Y, Quan J, Ning X, Zhu LM, Jiang B, He ZY. 2009. Lipase-catalyzed transesterification of soybean oil for biodiesel production in tert-amyl alcohol. World $J$. Microbiol. Biotechnol. 25, 41-46. https://doi.org/10.1007/ s11274-008-9858-4 